\title{
MENOSCABO Y COMPENSACIÓN ECONÓMICA. JUSTIFICACIÓN DE UNA VISIÓN ASISTENCIAL
}

\author{
José Luis Guerrero Becar*
}

\begin{abstract}
RESUMEN
La compensación económica, en particular los artículos 61 y 62 de la Ley de Matrimonio Civil, no ha estado exenta de discusión doctrinal, ya que no es clara en su redacción, sentido y alcance. La doctrina ha intentado dilucidar su naturaleza jurídica y conforme a ello poder interpretar las normas citadas. Paralelamente la jurisprudencia ha sido vacilante, en cuanto existen tendencias desde una lectura estricta del art. 61 de la LMC como requisito de procedencia de la institución a otras que se centran en los elementos que a título ejemplar menciona el legislador en el Art. 62 de la LMC, aun prescindiendo del art. 61 de la LMC. Sin embargo, se advierte una tendencia asistencial en la aplicación de la institución proveniente de la tradición en materia de familia de la institución de los alimentos. La compensación económica no son alimentos, pero tiene elementos que permiten determinar un sentido y alcance asistencial respecto del cónyuge más débil.
\end{abstract}

COMPENSACIÓN ECONÓMICA - DERECHO DE FAMILIA - DERECHO CIVIL

\section{Reduction and economical compensation. Justification of welfare vision}

\begin{abstract}
Economical compensation, particularly articles 61 and 62 of the Civil Marriage act, hasn't been exempt from doctrinal discussion because of its lack of clarity in its drafting, sense and approach. The doctrine has tried to elucidate its legal nature in order to interpret the cited norms. Also, the courts had been hesitant as they came from tendencies shown in strict readings of article 61 from the Civil Marriage Law as a requisite of the institutions' admissibility, towards others that center in elements that as exemplary titles mention the legislator in article 62 of the Civil Marriage Law, though dispensing article 61 of the Civil Marriage Law. However, a welfare tendency in the application of the institution is observed, coming from the tradition in family matters within the alimony institution. Economical compensation is not alimony but has elements that allow determining a welfare sense and approach from the weaker spouses' point of view.
\end{abstract}

ECONOMICAL COMPENSATION - FAMILY LAW - CIVIL LAW

* Abogado, Magíster en Derecho, Profesor de la Escuela de Derecho de la Pontificia Universidad Católica de Valparaíso, Avenida Brasil 2950. Valparaíso, Chile, jose.guerrero@ucv.cl. El autor agradece a la profesora de derecho civil de la Escuela de Derecho de la Pontificia Universidad Católica de Valparaíso Claudia Mejías Alonzo por sus valiosos comentarios respecto a este artículo. Artículo recibido el 30 de junio de 2008 y aceptado para su publicación el 24 de octubre de 2008. 


\section{UNA VISIÓN GENERAL DEL PROBLEMA}

$\mathrm{L}$ a compensación económica es una institución relativamente nueva en el derecho matrimonial chileno; fue incorporada por la Ley $\mathrm{N}^{\circ} 19.947^{1}$ dentro de las reglas comunes a la separación, nulidad y divorcio. ${ }^{2}$ La compensación económica es una de las instituciones que actualmente en el derecho chileno presenta mayores dificultades en su interpretación doctrinal y aplicación jurisprudencial.

La diversidad de visiones sobre los supuestos de procedencia, naturaleza jurídica y efectos de la compensación económica ${ }^{3}$ se presenta generalizadamente en la jurisprudencia nacional sobre esta institución. Lo anterior es entendible atendido que se trata de los primeros fallos que aplica la ley, pero cuestionable por la falta de certeza que se entrega a las partes, vulnerando uno de los principios y fines básicos del derecho.

Al panorama descrito se suma lo sostenido por la autoridad administrativa, específicamente el Servicio de Impuestos Internos, que en el año 2005, un año después de la entrada en vigencia de la ley, interpretó que la compensación económica no puede considerarse, para los efectos de la Ley de la Renta, como daño emergente ni tampoco como lucro cesante, sino que debe estimarse que tiene la calidad de daño moral, ${ }^{4}$ lo anterior, sin mayores cuestionamientos de la doctrina civil nacional atendido que se referiría a una materia especial como es la tributación. Sin embargo,

${ }^{1}$ La Ley N 19.947 entró en vigencia el día 17 de noviembre de 2004, seis meses después de su publicación en el Diario Oficial.

${ }^{2}$ Como ya ha precisado nuestra doctrina, a partir del propio tenor del artículo 61, la compensación económica sólo procede en los casos de término del matrimonio por nulidad y divorcio, ya que a pesar de que el epígrafe del Párrafo $1^{\circ}$ del Capítulo VII incluye los casos de separación, existe un error en su denominación, atendido que la compensación económica no está prevista en los casos de subsistencia del vínculo matrimonial, lo que se ve reafirmado en las propias disposiciones de dicho párrafo. Véase Barrientos, J./ Novales, A. Nuevo derecho matrimonial chileno, LexisNexis, Santiago, 2005, p. 402.

${ }^{3}$ Véase Guerrero, J. L., "La compensación económica en la ley de matrimonio civil: análisis jurisprudencial y sobre la necesidad de revisar los supuestos de procedencia”, en Revista de Derecho, Pontificia Universidad Católica de Valparaíso, vol. XXVII, 2006, 2º semestre, pp. 55-94; Zavala, J. L./Montesinos, C., Jurisprudencia sobre divorcio, Puntolex, Santiago, 2006; Turner, S., "Sentencia sobre requisitos de procedencia y finalidad de la compensación económica (Corte de Apelaciones de Valdivia)", en Revista de Derecho, Universidad Austral de Chile, vol. XIX, diciembre 2006, pp. 265-273.

${ }^{4}$ Así lo ha expresado el Servicio de Impuestos Internos en Oficios 4.605 y 4.606, ambos de fecha 18 de noviembre de 2005, de su Director Nacional. En el oficio 4.605 fundamenta su conclusión en: "El daño moral, a diferencia del daño emergente y lucro cesante, pretende compensar los daños sufridos en la esfera más íntima y, por tanto, no patrimonial de la víctima. No altera lo expuesto el que la propia Ley $\mathrm{N}^{\circ} 19.947$ emplee la expresión "menoscabo económico", pues, de lo contrario, la dedicación al cuidado de los hijos o a las labores propias del hogar común debiera considerarse, por sí misma, un daño patrimonial indemnizable. Lo que confiere caracteres extrapatrimoniales a la compensación es el hecho de que tales cuidados o labores propias del hogar común pueden restringir o cancelar las posibilidades de un desarrollo personal en otras esferas. Por cierto, no es que la imposibilidad o entorpecimiento de una actividad remunerada o lucrativa no tenga efectos económicos; sin embargo, tal como se concibe la compensación analizada, es claro que se pretende compensar el sufrimiento o daño ocasionado en la esfera de los afectos o sentimientos del cónyuge que ha debido renunciar o postergar un proyecto personal de desarrollo profesional o laboral, daño que se manifiesta con ocasión del divorcio o nulidad del matrimonio". Texto completo de Oficios disponible en www.sii.cl 
no deja de llamar la atención que la doctrina civil no se haya pronunciado sobre la interpretación que de la naturaleza jurídica de la compensación hizo el Servicio de Impuestos Internos, sino hasta que se advirtiera que éste estimara, por oficio $\mathrm{N}^{\circ} 2890$ de 11 de octubre de 2007, que las sumas percibidas por compensación económica no eran renta de conformidad al inciso 1, del número 1 del artículo 17 de la Ley sobre Impuesto a la Renta, ${ }^{5}$ en la medida que sean declaradas mediante sentencia judicial, por lo que si ésta es acordada mediante avenimiento o transacción en virtud del artículo 63 de la Ley de Matrimonio Civil, sí son constitutivas de renta. ${ }^{6}$

El conocimiento público del señalado oficio inició una rápida discusión pública, que terminó con la intervención del Ejecutivo, enviando el 28 de noviembre de 2007 un proyecto de ley ${ }^{7}$ que libera del impuesto a la renta a las compensaciones económicas originadas al término del matrimonio, derivado -dice derechamente- del hecho de que la compensación económica no es renta.

En los fundamentos del mensaje cabe destacar la siguiente argumentación del Ejecutivo: "La Ley $N^{o}$ 19.947, que establece nueva Ley de Matrimonio Civil, otorga un explícito reconocimiento al aporte económico del trabajo doméstico, al consagrar la posibilidad que un cónyuge pueda percibir del otro, con ocasión del término del matrimonio, una compensación

${ }^{5}$ Art. $17 \mathrm{~N}^{\mathrm{o}} 1$ inciso 1 de la Ley sobre Impuesto a la Renta: “Artículo $17^{\circ}$.- No constituye renta: $1^{\circ}$.- La indemnización de cualquier daño emergente y del daño moral, siempre que la indemnización por este último baya sido establecida por sentencia ejecutoriada".

${ }^{6}$ Oficio 2890 de 11 de octubre de 2007 del Director Nacional del Servicio de Impuestos Internos, "Tratamiento tributario de compensación económica acordada entre las partes mediante transacción en juicio de divorcio al amparo del artículo $63^{\circ}$ de la Ley $\mathrm{N}^{\circ} 19.947$, sobre Matrimonio Civil”. En este oficio, cabe destacar las siguientes argumentaciones del SII: “4. Los Oficios anteriormente indicados evidencian que si bien el criterio de este Servicio es considerar que la naturaleza jurídica de la compensación económica establecida en el artículo 61 de la Ley N 19.947, sobre Matrimonio Civil, como la de una indemnización por daño moral, no es menos cierto que de acuerdo con lo dispuesto por el artículo $17 \mathrm{~N}^{\circ} 1$ de la Ley de la Renta, la indemnización por daño moral constituirá un ingreso no renta, sólo en la medida que haya sido establecida por sentencia ejecutoriada. 7.- Se concluye entonces que las sumas recibidas por un cónyuge originadas en una indemnización convencional pactada con el otro mediante un avenimiento o transacción, de acuerdo a lo previsto en el artículo 63 de la Ley No 19.947, sobre Matrimonio Civil, constituye para la parte que la reciba un ingreso afecto a la tributación normal establecida en la Ley de la Renta, esto es, al impuesto de Primera Categoría y Global Complementario o Adicional, según proceda”.

${ }^{7}$ Mensaje de la Presidenta de la República, No 1105-355 de fecha 28 de noviembre de 2007 "Proyecto de ley que libera del impuesto a la renta a las compensaciones económicas originadas al término de un matrimonio”. Se propone incorporar al Art. 17 de la Ley de Impuesto a la Renta, que determina los ingresos no constitutivos de renta, el siguiente numeral: " $31^{\circ}$.- Las compensaciones económicas convenidas o determinadas a favor de un cónyuge en conformidad a la Ley $\mathrm{N}^{\circ}$ 19.947. Para efectos de aplicar lo establecido en los artículos 63 y 64 de la Ley $N^{\circ} 16.271$ sobre Impuesto a las Herencias, Asignaciones y Donaciones, y de lo establecido en el artículo 70 de la Ley sobre Impuesto a la Renta, el Servicio de Impuestos Internos podrá requerir de los tribunales de familia los antecedentes que sirvan de base al acuerdo de los cónyuges o de la sentencia, así como de las valorizaciones de las compensaciones que consistan en bienes distintos de dinero, depósitos a plazo u otros igualmente líquidos".

El señalado proyecto fue aprobado por la Cámara de Diputados - por 101 votos a favor de 120 posiblesy por el Senado, trasformándose en la Ley N $N^{\circ} 20.239$ publicada en el Diario Oficial de fecha 8 de febrero de 2008. Como es posible apreciar, en no más de tres meses se puso término legislativamente a la discusión si la compensación económica es constitutiva de renta o no. 
del menoscabo económico en los términos del artículo 61, esto es, si como consecuencia de haberse dedicado al cuidado de los hijos o a las labores propias del hogar común, no pudo desarrollar una actividad remunerada o lucrativa durante el matrimonio, o lo bizo en menor medida de lo que podía y quería". Como se puede apreciar, el Ejecutivo en su mensaje vincula la compensación económica a los supuestos del artículo 61 de la LMC, y más específicamente al “aporte económico del trabajo doméstico", es decir, restringe su ámbito de aplicación a dicho supuesto, por lo que si no existió trabajo doméstico, es posible entender que en la visión del Ejecutivo no debiera proceder esta institución.

A todo lo anterior se suma un nuevo antecedente legislativo, la Ley $\mathrm{N}^{\circ} 20.255 .{ }^{8}$ Ella dispone que es posible el pago de compensación económica a través del traspaso de los fondos previsionales del cónyuge deudor hasta en un $50 \%$ de los mismos. Estos fondos serán traspasados a la cuenta de capitalización individual del cónyuge acreedor, que si carece de ella se le abrirá una a dicho efecto. Conforme a esta ley, el monto de compensación no será de libre disposición del acreedor, como sí lo sería un monto en dinero propio de una indemnización, sino que se incorporará al sistema y reglas generales del sistema previsional, por lo que es fácil advertir su sentido asistencial. El artículo 80 de la Ley 20.255 hace procedente esta modalidad al "considerar la situación en materia de beneficios previsionales a que se refiere el Art. 62 de la Ley 19.947”. El tenor literal parece apuntar a que sólo se refiere a ese caso, y por tanto se podría establecer un monto adicional de compensación, en caso de proceder, conforme a los otros factores a considerar, de lo que nos haremos cargo más adelante en este artículo.

El panorama descrito parece nebuloso, casi caótico. Aún no contamos con una visión unitaria en la jurisprudencia respecto a cómo interpretar la institución; los órganos de la administración estatal como el Servicio de Impuestos Internos tienen su propia interpretación, y la doctrina nacional también tiene diversas visiones de cómo han de interpretarse los artículos 61 y 62 de la LMC.

${ }^{8}$ D.O. 17 marzo 2008. Dicha ley, en su título III, párrafo segundo, dispone: "Compensación económica en materia previsional en caso de nulidad o divorcio: Art. 80. Al considerar la situación en materia de beneficios previsionales a que se refiere el artículo 62 de la Ley $N^{\circ}$ 19.947, sobre Matrimonio Civil, y ello origine total o parcialmente un menoscabo económico del que resulte una compensación, el juez, cualquiera haya sido el régimen patrimonial del matrimonio, podrá ordenar el traspaso de fondos desde la cuenta de capitalización individual afecta al decreto ley $N^{o} 3.500$, de 1980, del cónyuge que deba compensar a la cuenta de capitalización del cónyuge compensado o de no existir ésta, a una cuenta de capitalización individual, que se abra al efecto. Dicho traspaso no podrá exceder del $50 \%$ de los recursos acumulados en la cuenta de capitalización individual del cónyuge que debe compensar, respecto de los fondos acumulados durante el matrimonio. Art. 81. La Superintendencia de Pensiones deberá tener a disposición de los tribunales estudios técnicos generales que contribuyan a resolver con bases objetivas la situación previsional que involucre a cónyuges. De estimarlo necesario, el juez podrá requerir al citado organismo antecedentes específicos adicionales. La Superintendencia establecerá, mediante norma de carácter general, los procedimientos aplicables en los traspasos de fondos, apertura de las cuentas de capitalización individual que se requirieran y demás aspectos administrativos que procedan". Estas normas entrarán en vigencia el 1 de octubre de 2008. 


\section{NATURALEZa JURÍdica DE LA INSTitución.} ESTADO DE LA CUESTIÓN

En la doctrina nacional, a pesar del poco tiempo de existencia legal, mucho se ha escrito acerca de la naturaleza jurídica de la compensación económica; existen diversas teorías que han sido recogidas por nuestra jurisprudencia sin que pueda advertirse uniformidad al respecto, incluso podríamos llegar a afirmar que hay tantas teorías como autores en el tema, sin que necesariamente la naturaleza jurídica atribuida se proyecte a cabalidad, posteriormente, cuando se efectúa el análisis de los requisitos de procedencia de la institución. Lo anterior se debe, como ya hemos mencionado, a lo confuso de la regulación -incluso manifestada en la discusión parlamentaria- ${ }^{9}$ que permite fundar estas teorías en los propios términos empleados por el legislador.

Antes de presentar un panorama de estas teorías resultará de utilidad contextualizar la institución. La compensación económica está prevista en la Ley N¹9.947 como un efecto común a la declaración de divorcio y nulidad. Ambos de conformidad al artículo 42 de la LMC son causales de término del matrimonio, el primero como una causal sobrevenida que incide en los efectos del matrimonio en cuanto institución, la segunda, como una causal que presupone un vicio al momento de la celebración del matrimonio, incidiendo en los efectos del matrimonio en cuanto contrato. Es pues el matrimonio, su término, el que da lugar a la compensación económica, una vez que concurren sus requisitos de procedencia.

El matrimonio en el Código Civil tras la entrada en vigencia de la LMC no sufrió alteraciones en su concepto; el artículo 102 se ha mantenido intacto -a pesar de que se debatió acerca de su modificación-, se le sigue considerando como aquel contrato solemne por el cual un hombre y una mujer se unen actual e indisolublemente y por toda la vida, con el fin de vivir juntos, procrear y de auxiliarse mutuamente. Hay tras esta noción de matrimonio la idea de un consorcio o comunidad de vida ${ }^{10}$ y, podríamos decir, por toda la vida -al menos como una aspiración del legislador como quedó reflejada en la historia fidedigna del establecimiento de esta ley-. Esta comunidad de vida que el matrimonio es conduce a que, probablemente, los cónyuges deberán renunciar a oportunidades de toda índole (laborales, de desarrollo personal, etc.) para privilegiar el bienestar de la familia común; son los cónyuges quienes están obligados a soportar las cargas del matrimonio, entendidas como aquellos desembolsos que deben hacerse para el establecimiento, mantención y desarrollo de la familia común. ${ }^{11}$ Además, no debe

\footnotetext{
${ }^{9}$ Sobre este punto, con mayor detalle Barrientos, J./Novales, A. cit. n. 2.

${ }^{10}$ Ello se desprende claramente en las nuevas causales de nulidad del matrimonio introducidas por la LMC, en especial el artículo $5 \mathrm{~N}^{\text {os. }} 3$ y 4.

${ }^{11}$ Ello puede afirmarse aun con prescindencia del régimen económico matrimonial, pues las normas que regulan esta materia obligan, por regla general, a los cónyuges a contribuir a las necesidades de la familia común atendidas sus capacidades económicas -es lo que acontece si el régimen de bienes es de separación total o el régimen de participación en los gananciales [arts. 134, 160, 1792-2]-y si el régimen de bienes es el de sociedad conyugal, es ésta precisamente la encargada de asumirlas, forman parte de su pasivo absoluto, lo que obedece a la funcionalidad del sistema: comunidad restringida de gananciales con la particularidad de
} 
perderse de vista que los padres son los obligados a velar por el cuidado personal de sus hijos, a mantener con ellos una relación directa y regular, sin perjuicio de los derechos y obligaciones de carácter patrimonial. Tras las decisiones que los cónyuges tomen hay una opción, y el costo de oportunidad que ella involucra durante la vigencia del matrimonio, por las implicancias de esta comunidad de vida, pasa inadvertido. El verdadero problema se producirá a su término, y es aquí donde se inserta esta institución, decimos a su término porque es en ese momento en que deberá apreciarse si existe o no un menoscabo económico como consecuencia de la declaración de divorcio o nulidad.

A continuación se ahondará en la discusión acerca de la naturaleza jurídica de la compensación económica, las principales teorías que nuestra doctrina ha planteado discurren acerca de su naturaleza jurídica reparatoria, asistencial, variable o sui géneris.

\section{A. Naturaleza jurídica reparatoria}

La mayor parte de la doctrina nacional sobre la base de los propios términos empleados por el legislador - "compensar", el "menoscabo económico"- ha sostenido la vinculación de esta institución con la noción de indemnización atribuyéndole una naturaleza jurídica reparatoria; ${ }^{12}$ sin embargo, pueden subdistinguirse diversas variantes:

1) Para algunos, esta institución tiene una naturaleza jurídica reparatoria del menoscabo producido al término del matrimonio, siguiendo el modelo español de la pensión compensatoria, reconociéndose sí que existen diferencias de forma y fondo con relación a ésta que conducen a que ella no traduzca fielmente dicha naturaleza.

Tratándose del fondo, que es el aspecto que nos interesa destacar por su vinculación con el presupuesto de procedencia de la compensación económica, se ha colocado énfasis en que el modelo chileno presenta imprecisiones en cuanto a su supuesto de hecho, pues en el derecho español el concepto clave es el desequilibrio económico, mientras a que a la luz del artículo 61 de la LMC lo es el menoscabo económico producido por el hecho de que uno de los cónyuges no desarrollara actividad remunerada o lucrativa alguna o lo hiciera en menor medida de lo que podía y quería, a consecuencia de haberse dedicado al cuidado de los hijos o a las labores propias del hogar común. ${ }^{13}$

la situación de los bienes muebles aportados o adquiridos a título gratuito; en último término, son también los cónyuges quienes contribuyen a satisfacer estas necesidades.

${ }^{12}$ Es preciso aclarar que la mayoría de los autores que se inclinan por sostener una naturaleza jurídica reparatoria a la institución descartan confundirla con la indemnización del lucro cesante, con una genuina indemnización de perjuicios en los términos previstos en el Código Civil. Por todos, véase Pizarro Wilson, Carlos, "La compensación económica en la nueva ley de matrimonio civil chilena", en Academia Judicial, Seminario de la Ley No 19.947 de matrimonio civil, 13 y 14 de octubre de 2004, pp. 72 y ss.

${ }^{13}$ En este sentido, Turner, S., "Las prestaciones económicas entre cónyuges divorciados en la nueva ley de matrimonio civil”, en Revista de Derecho, Universidad Austral de Chile, vol. XVI, julio 2004, pp. 83-104. 
Desde esta perspectiva, siguiendo la tesis subjetiva del derecho español, la relación entre los artículos 61 y 62 de la LMC es la de una vinculación de dependencia funcional; la primera de las normas sería principal al definir el presupuesto de la compensación económica, la segunda meramente auxiliar al incidir en su cuantía o para determinar que el menoscabo económico no existe a pesar de haberse dedicado uno de los cónyuges al cuidado de los hijos y a las labores propias del hogar común. En síntesis, no todo menoscabo económico sufrido por uno de los cónyuges a consecuencia del matrimonio será cubierto por la compensación económica, sólo si al matrimonio ha seguido la dedicación de uno de los cónyuges al cuidado de los hijos o a las labores propias del hogar común, sin trabajar remuneradamente. ${ }^{14}$

2) Para otros, su naturaleza jurídica se condice con un tipo de indemnización por afectación legal de derechos: la asistencia económica del estatuto matrimonial. El profesor Corral, quien sostiene esta postura, asimila esta indemnización a aquellas que se pagan en caso de expropiación o de imposición de servidumbres legales.

Es decisivo en la naturaleza jurídica atribuida el modelo, o caso central tenido en vista por los legisladores, que el autor centra en la mujer que, normalmente habiendo llevado el mayor peso de las responsabilidades de la familia, es objeto del divorcio por voluntad unilateral de su marido.

Teniendo en cuenta lo anterior, se postula la armonización de los artículos 61 y 62, partiendo del supuesto de hecho fundamental: que se produzca un menoscabo económico, menoscabo que la mayor parte de las veces se producirá en el supuesto del artículo 61 -lo que justificaría estar en el primer precepto-; pero también puede producirse por cualquiera de las circunstancias previstas en el artículo 62.

3) Se ha sostenido también que esta institución tiene un carácter indemnizatorio, aun cuando no se trate de un supuesto propio de responsabilidad civil. Se trata de una forma de resarcir un cierto daño: la pérdida producida por el hecho de haber dedicado el esfuerzo de la vida al cuidado de los hijos o a las tareas del hogar que ha impedido una vida de trabajo con resultados económicos, una indemnización por el costo de oportunidad laboral perdido que le permita al cónyuge más débil comenzar su vida futura separada.

El carácter indemnizatorio que se le atribuye a esta institución no se hace sinónimo en rigor de "reparar", no se trata de restituir un valor perdido por su equivalente exacto como ocurre en los casos de responsabilidad civil por daño patrimonial, sino sólo de ofrecer una satisfacción económica que mitigue la situación económica desmedrada del demandante. ${ }^{15}$

${ }^{14}$ Cfr. Turner, S., "La compensación económica en la ley de matrimonio civil", en Revista Chilena de Derecho, Pontificia Universidad Católica de Santiago, vol. XXXII, julio 2005, pp. 421-427.

${ }^{15}$ Cfr. Domínguez Águila, R., "La compensación económica en la nueva legislación de matrimonio civil", en Actualidad Jurídica, Universidad del Desarrollo, vol. XV, 2007, pp. 88-90.

Cabe hacer presente que hay autores que reconociéndole una naturaleza jurídica reparatoria estiman que no cabe aplicar supletoriamente las normas contenidas en el Título XXXV del Libro IV del Código Civil pues las normas que las regulan están en la ley debiendo la doctrina y jurisprudencia extraer de ellas sus prin- 
De esta perspectiva, los artículos 61 y 62 cumplen la función de precisar los requisitos de la institución. El artículo 61 sirve para fijar tres requisitos: a) que el demandante de compensación se haya dedicado durante el matrimonio al cuidado de los hijos y a las labores propias del hogar común; b) que a consecuencia de lo anterior no haya desarrollado una actividad remunerada como quería y podía; y c) que se produzca un menoscabo económico. Por su parte, el artículo 62 permite acreditar y probar el menoscabo económico y su monto, elemento vinculado causalmente a la dedicación de los hijos o a las labores del hogar. ${ }^{16}$ Dicho en otros términos, el menoscabo económico es consecuencia de que uno de los cónyuges no pudo dedicarse a una actividad remunerada durante el matrimonio o lo hizo en menor medida de lo que quería y podía por haberse dedicado al cuidado de los hijos o a las labores propias del hogar común. ${ }^{17}$

4) La doctrina también ha sostenido que la compensación económica presenta un marcado carácter indemnizatorio por el enriquecimiento del cónyuge deudor y el empobrecimiento del cónyuge beneficiario. Por lo anterior, se explica su naturaleza jurídica por medio del enriquecimiento a expensas de otro.

A través de la compensación económica se pretende indemnizar al cónyuge beneficiario por la pérdida de un estándar de vida que tenía durante la vida conyugal por haberse dedicado al cuidado de los hijos o a las labores propias del hogar común. Este trabajo desempeñado por el cónyuge beneficiario es el que ha originado un enriquecimiento del cónyuge deudor, quien goza de un cierto nivel de vida gracias al sacrificio del otro. En estos casos el empobrecimiento se traduce en una merma económica o en la ausencia de ingresos en el patrimonio del cónyuge beneficiario.

De esta perspectiva los artículos 61 y 62 fijan los requisitos de procedencia de la institución y debe agregarse como condición de procedencia el análisis y descarte de la liquidación del régimen económico matrimonial, sin perjuicio de que tratándose del menoscabo económico hay casos en que él se presume como en aquellos casos en que el matrimonio ha tenido una larga duración y el cónyuge beneficiario se ha dedicado exclusivamente al cuidado de los hijos o a las labores propias del hogar. ${ }^{18}$

cipios. Cfr. Domínguez, C., "El convenio regulador y la compensación económica: una visión de conjunto”, en Corral, H. (coord.), Matrimonio civil y divorcio, Universidad de los Andes, Santiago, 2005, p. 106.

${ }^{16}$ Domínguez Águila, R., cit. n. 15, pp. 87-92.

${ }^{17}$ Cfr. Barrientos, J./Novales, A., cit. n. 2, pp. 424 y ss. Estos autores precisan que este menoscabo se manifiesta en dos ámbitos: a) lo que el cónyuge dejó de percibir o ganar, como consecuencia de no haber desarrollado una actividad lucrativa o haberlo hecho en menor medida de lo que podía y quería; b) El perjuicio consistente en el costo de oportunidad laboral, por no haber podido prepararse y desarrollarse profesionalmente para mantener o incrementar sus posibilidades de acceso al trabajo en condiciones de mercado.

18 Pizarro, C., cit. n. 12, pp. 73-74. 


\section{B. Naturaleza jurídica asistencial}

Sobre la base de lo dispuesto en el artículo 60 y otras disposiciones contenidas en el párrafo $1^{\circ}$ del capítulo VII, en especial los artículos 62 y 66 y de la propia discusión parlamentaria se ha discutido la naturaleza jurídica asistencial a esta institución como una forma de paliar la extinción del deber de socorro y del estatuto protector que confiere el matrimonio. En efecto, el artículo 60 prescribe que el divorcio pone fin a las obligaciones y derechos de carácter patrimonial cuya titularidad y ejercicio se funden en la existencia del matrimonio, sin perjuicio de lo dispuesto en el párrafo de la compensación económica. Por su parte, el artículo 62 enumera como factor, para determinar la existencia del menoscabo económico y la cuantía de la compensación: la situación patrimonial de los cónyuges, su estado de salud, previsional o cualificación profesional.

No existe duda doctrinal en el hecho de que la compensación económica no constituye alimentos, ya que la LMC se preocupa de aclarar en su Art. 66 que sólo para los efectos de cumplimiento de la compensación económica se asimilará ésta a los alimentos. El que la compensación económica no tenga naturaleza de alimentos no implica que no pueda tener un fundamento asistencial.

El fundamento asistencial ${ }^{19}$ está presente en diversas instituciones del derecho chileno. El apoyo económico frente a un estado de necesidad se manifiesta desde el propio artículo $1^{\circ}$ inciso $3^{\circ}$ del texto constitucional que dispone que el Estado está al servicio de la persona humana y su finalidad es promover el bien común, para lo cual debe contribuir a crear las condiciones sociales que permitan a todos y a cada uno de los integrantes de la comunidad nacional su "mayor realización espiritual y material posible", con pleno respeto a los derechos y garantías que esta Constitución establece, lo que se reafirma con el deber del Estado de dar protección a la población y a la familia. La propia LMC recoge esta visión en su Art. 3 que dispone como principio inspirador el interés superior de los hijos y del cónyuge más débil, aún después de terminado el matrimonio, al disponer que el juez resolverá las cuestiones de nulidad o divorcio conciliándolas con "la subsistencia de una vida familiar compatible con la ruptura o la vida separada de los cónyuges”, es decir, prevé que aún sin matrimonio puedan existir relaciones patrimoniales entre los cónyuges, lo que reafirma el Art. 60 de la LMC, al excluir del término de las relaciones patrimoniales precisamente a la compensación económica.

Las prestaciones asistenciales para hacer frente a estados de necesidad pueden entregarse por el Estado o por los propios particulares. El Estado actúa como prestador directo en diversas ocasiones, como las pensiones mínimas de vejez o gratuidad en atención de salud a sectores de escasos recursos, pero también es posible que sean los propios particulares los que entreguen esta protección y prestación derivados de relaciones contractuales o familiares que al romperse requieren de protección para el más débil. El derecho del trabajo es prolífico en esta mirada asistencial posrelación contractual, por ejemplo, en materia de seguro de cesantía en que parte de la cotización la entrega

19 “Asistencial”, conforme a la Real Academia de la Lengua Española, significa "Perteneciente o relativo a la asistencia, especialmente la médica o la social”. 
el empleador, o bien en materia de accidentes del trabajo y enfermedades profesionales. En materia de familia, terminada la relación matrimonial, es perfectamente posible que el legislador, atendido el término del deber de socorro que corresponde a los cónyuges pero precaviendo la posibilidad de un cónyuge más débil, esto es, un cónyuge que se encuentre en un estado de necesidad originada durante el matrimonio o con ocasión de su término, contemple una nueva institución asistencial, con justificación distinta a la del vínculo de parentesco como en los alimentos, pero que se base en un estado de necesidad que el legislador estima necesario enfrentar, reparar o compensar, y esta función cumpliría la compensación económica, precisamente porque no puede perdurar luego del matrimonio el derecho de alimentos.

Lo anterior encontraría fundamento en la historia de la LMC según se revisará más adelante, en el texto de los artículos 3 y 60 de la LMC y en leyes especiales dictadas con posterioridad a la LMC, como lo es la Ley 20.239 publicada el 8 de febrero de 2008 que declara exenta del impuesto a la renta a la compensación económica, o particularmente en la Ley $\mathrm{N}^{\circ} 20.255$ sobre reforma del sistema previsional chileno, publicada el 17 de marzo de 2008, que en el marco de una visión asistencial de políticas públicas en materia de seguridad social incorpora en los artículos 80 y 81 un párrafo que trata sobre “compensación económica en materia previsional en caso de nulidad o divorcio".

Esta visión asistencial no es extraña en el derecho comparado, y creo es cercana a los fundamentos que la doctrina italiana entrega para la institución del assegno divorzile, en que una vez terminado el deber de socorro entre los cónyuges por el divorcio, "la asignación se sitúa en la necesidad de dar tutela existencial a uno de los cónyuges que, como consecuencia de haber desaparecido la solidaridad familiar, se encuentra en un estado de necesidad, mientras el otro goza de adecuados réditos propios, de manera que el elemento justificativo de esta especial obligación que la ley impone a uno de los cónyuges se halla en una cierta ultaactividad de la solidaridad familiar". ${ }^{20}$

\section{Naturaleza jurídica variable}

Algunos autores, vinculando los artículos 61 y 62 como normas que establecen los requisitos de procedencia de la compensación económica, en especial los factores a considerar para determinar la existencia y cuantía del menoscabo económico, concluyen que la compensación económica tiene una naturaleza jurídica variable:

a) La mayor parte de las veces tendría naturaleza jurídica indemnizatoria, fundada en el principio del enriquecimiento sin causa, principalmente en aquellos casos en que se otorga al cónyuge que no pudo desarrollar una actividad remunerada o lucrativa durante el matrimonio o lo hizo en menor medida de lo que quería y podía, debiendo considerarse especialmente la duración de la vida en común de los cónyuges.

${ }^{20}$ Ver comentarios sobre la asignación en el divorcio, assegno divorzile, en el derecho italiano, en Barrientos, J./Novales, A., cit. n. 2, pp. 412-414. 
b) Tendrá naturaleza jurídica asistencial en aquellos casos en que se conceda al cónyuge basado únicamente en su estado de salud o en su situación en materia de beneficios previsionales y de salud, o bien

c) Tendrá naturaleza jurídica alimenticia en aquellos casos en que se conceda al cónyuge basado en su mala situación patrimonial o su baja calificación profesional o sus pocas posibilidades de acceder al mercado laboral. ${ }^{21}$

\section{Naturaleza jurídica sui géneris}

Finalmente están autores que negando las posibilidades anteriores por no concurrir a cabalidad sus requisitos, según el derecho común, le atribuyen una naturaleza jurídica sui géneris ${ }^{22}$ que presenta sólo cierta cercanía con estas instituciones conocidas del derecho civil.

La compensación económica sería una obligación legal impuesta a uno de los ex cónyuges cuyo objeto es corregir el desequilibrio económico que el divorcio o la nulidad produce. En estos casos existe una reacción del ordenamiento jurídico frente al menoscabo económico, no para repararlo sino para corregirlo, previniéndose así un empeoramiento de la vida futura del cónyuge más débil, sin que ello implique igualar el patrimonio de ambos cónyuges. ${ }^{23}$

Para estos autores el artículo 61 fija los requisitos, sumándose a los tradicionalmente señalados que el menoscabo económico impida relaciones equitativas hacia el futuro. El artículo 62 denotaría el carácter subjetivo del menoscabo económico y haría necesaria la proyección hacia el futuro de las condiciones económicas que puede alcanzar el cónyuge afectado después del divorcio o nulidad, sobre la base de un juicio de previsibilidad que se asienta en los criterios previstos en dicha norma, algunos de ellos miran al pasado -la causa del menoscabo (duración del matrimonio, vida en común, colaboración en una actividad lucrativa); otros se refieren al presente (situación patrimonial, edad, estado de salud, materia de beneficios de previsión y estado de salud); finalmente, otros miran el futuro, a la posibilidad del cónyuge beneficiario de acceder al mercado laboral y sus ingresos futuros (posibilidad de acceso al mercado laboral, cualificación profesional). ${ }^{24}$

${ }^{21}$ Cfr. Court, E., Nueva Ley de Matrimonio civil (Ley 19.947 de 2004 analizada y comentada, Legis, Santiago, 2004, pp. 97-99.

${ }^{22}$ En este sentido, Veloso, P., “Algunas reflexiones sobre la compensación económica”, en Actualidad Jurídica, Universidad del Desarrollo, vol. XIII, 2006, pp. 186-187.

${ }^{23}$ Vidal, A., "La compensación por menoscabo económico en la ley de matrimonio civil, en Vidal. A./ Guzmán Brito, A. (coord.), El nuevo derecho chileno del matrimonio, Editorial Jurídica de Chile, Santiago, 2006. En este sentido, el autor afirma que "Al momento de contraer matrimonio cada uno de los cónyuges tendrá que contar con la posibilidad que si el otro cónyuge durante su vigencia deja de desarrollar una actividad remunerada por dedicarse a la familia y sobreviene su terminación, podrá quedar obligado, atendidas ciertas circunstancias, a pagar una suma de dinero o una prestación suficiente para que el beneficiario rehaga su vida separada y consiga un status económico autónomo adecuado al que poseía constante el matrimonio”.

${ }^{24}$ Veloso, P., cit. n. 22, pp. 178-181. 


\section{Aproximación a UnA Visión INTEgRAdORA FUNDADA EN EL CONCEPTO ASISTENCIAL}

La doctrina según se ha podido apreciar tiene distintas visiones de esta institución, en cuanto a su naturaleza jurídica y a la interpretación que debe darse a los artículos 61 y 62 de la LMC, siendo justo señalar que esta falta de uniformidad deriva de la poca claridad de estas disposiciones.

¿Es posible intentar una visión que permita conjugar las miradas hacia el pasado y hacia el futuro a las que se refieren los autores?

Necesariamente el tomar partido por alguna de las doctrinas de la naturaleza jurídica que tendría la compensación económica conllevará en su aplicación a la exclusión de supuestos fácticos en que, no obstante existir un cónyuge más débil, éste pueda no tener derecho a compensación económica, o bien que quien no lo sea, por ejemplo por tener un patrimonio personal importante, igualmente tenga derecho a compensación económica en reparación al menoscabo económico que le produjo el no poder dedicarse a su actividad profesional cuando podía y quería, como en el caso de una profesional exitosa que por cuidar del hogar común y sus hijos disminuye su actividad profesional obteniendo menores réditos de los que hubiese obtenido estando soltera. ¿El legislador habrá previsto estas exclusiones de cónyuges más débiles e inclusiones de cónyuges que no son más débiles, pero que sí han tenido un empobrecimiento relativo?

La jurisprudencia heterogénea que han producido nuestros tribunales así como la existencia de al menos cuatro posiciones doctrinales sobre la naturaleza jurídica de la compensación económica no nos permiten aún responder la pregunta anteriormente formulada, ya que queda claro que no existe consenso aún en el derecho chileno sobre el correcto sentido y alcance de la LMC en materia de compensación económica. Así, algunas visiones doctrinales y jurisprudencia se basan en que la compensación económica es de derecho estricto, en cuanto no es procedente si no se dan los supuestos del artículo 61 de la $\mathrm{LMC}^{25}$ aun cuando estén presentes los del artículo 62; otros estiman que es posible soslayar el artículo 61 de la LMC en cuanto al supuesto de trabajo doméstico, y centrarse en analizar la existencia de un menoscabo económico conforme a los parámetros de cuantificación del artículo $62,{ }^{26}$ y otros estiman que la mirada debe ser hacia el futuro atendiendo más bien al desequilibrio que produce el hecho mismo del divorcio, en vez de cuantificar el menoscabo económico de quien solicita la compensación económica por no poder trabajar cuando pudo y quiso. En este último sentido, una variante es Álvaro Vidal Olivares quien cita la teoría del "clean break" del common law, conforme a la cual las prestaciones entre divorciados deben ofrecer al cónyuge más débil una base cierta para afrontar de manera autónoma una vida definitivamente separada y así alcanzar un estatus adecuado al que tenía durante el matrimonio. El autor plantea

${ }^{25}$ Por ejemplo, ver Turner, S., cit. n. 3, p. 272.

${ }^{26}$ Ver Corral, H., "La compensación económica en el divorcio y la nulidad matrimonial”, en Revista Chilena de Derecho, Pontificia Universidad Católica de Santiago, vol. XXXIV, enero 2007, pp. 23-40. 
que la función de la compensación económica es reparar el desequilibro que se produce al momento del divorcio, desequilibrio que tiene sus causas en el pasado y corresponde corregir para el futuro, opinión que se comparte. Sin embargo, restringe la procedencia de la compensación económica al supuesto del artículo 61 de la $\mathrm{LMC},{ }^{27}$ con lo cual excluye los casos en que no presentándose los supuestos del Art. 61, igualmente uno de los cónyuges no puede afrontar luego del divorcio de manera autónoma una vida futura, por ejemplo, en el caso que la cónyuge trabajare pero con una remuneración muy inferior a la de su cónyuge, que mientras estuvo casada no presentaba inconveniente atendido el ingreso de ambos cónyuges pero que en vidas separadas le sea insuficiente para su subsistencia básica.

Ante este panorama, y con el riesgo de ser una más de las interpretaciones que contribuyen al caos interpretativo, se intentará a continuación una aproximación a una mirada integradora:

Parece advertirse de la historia de la ley que la institución de la compensación económica se incorporó para apoyar a la cónyuge que no desarrolló una actividad remunerada por dedicarse al trabajo doméstico que frente a un término del matrimonio se ve desamparada económicamente hacia el futuro ya que al perder la calidad de cónyuge pierde la calidad de alimentaria y todo el estatuto protector que le confiere el matrimonio.

La institución de la compensación económica surgió de indicaciones parlamentarias en el Senado de la República al proyecto del Ejecutivo, que originalmente no la preveía, ${ }^{28}$ por lo que el texto final no hubo de adscribirse plenamente a ninguna de las teorías seguidas en el derecho comparado para instituciones similares. ${ }^{29}$

${ }^{27}$ Ver Vidal, A., "Compensación económica en la Ley de Matrimonio Civil”, en Adame, J. (coord.), Derecho Civil y Romano, Cultura y sistemas jurídicos comparados, UNAM, México, 2006, p. 437, y Vidal, A., "La compensación económica en el divorcio y la nulidad matrimonial", en Revista chilena de derecho, Pontificia Universidad Católica de Santiago, Vol. XXXIV, enero 2007, pp. 23-40.

${ }^{28}$ Es posible revisar esta discusión en Informe de la Comisión de Constitución, Legislación, Justicia y Reglamento, recaído en el proyecto de ley, en segundo trámite constitucional, que establece una nueva ley de matrimonio civil. Boletín $\mathrm{N}^{\circ} 1.759-18$.

29 Tapia, M., "La compensación económica en la ley de divorcio", en Semana Jurídica, LexisNexis $\mathrm{N}^{\circ}$ 271, Santiago, 2006, pp. 4-5, señala: "En el caso chileno, si bien una primera indicación del Ejecutivo otorgaba a la compensación económica un carácter netamente 'asistencial' (como una pensión de alimentos que permitiría al cónyuge 'mantenerse' luego del divorcio y que se fijaba tomando en cuenta sus recursos) con posterioridad, en la Comisión de Constitución del Senado, se modificó su regulación para transformarla en un mecanismo de reparación de un menoscabo económico pasado, de la falta de ingresos por haberse dedicado a labores domésticas. Por esto, la compensación económica en la ley chilena tiene -al menos en las hipótesis más típicas- una naturaleza cercana a la reparación de la 'pérdida de una chance', pues se indemniza a un cónyuge cuya dedicación al hogar y a los hijos le hizo perder la oportunidad de ejercer un trabajo remunerado, aunque no se sabe con exactitud cuál habría sido ese trabajo, con qué intensidad lo habría asumido, qué ingresos habría recibido y cuál habría sido su proyección en el tiempo. Sólo se sabe que perdió una oportunidad de desarrollarlo. A continuación de esa definición de la compensación económica en la ley chilena (artículo 61) se reconocieron varios criterios de cálculo (artículo 62) que están tomados del derecho español y francés y que aparentemente introducen ambigüedad acerca del fin de esta institución y de sus fórmulas de cálculo". 
La visión mayoritaria de las sentencias de los primeros años de aplicación de la institución tuvo un marcado carácter asistencial, ${ }^{30}$ en ellas con la finalidad de apoyar al cónyuge más débil se asimiló la compensación económica, en la práctica, a la pensión alimenticia. En efecto, si bien no suele mencionarse expresamente esta equiparación, al momento de cuantificar la compensación es fácil advertir que el juez la ha considerado, incluso muchas veces se han fijado cuotas exactamente iguales a la pensión alimenticia que antes pagaba el cónyuge, ahora ex cónyuge deudor. ${ }^{31}$

Luego, teniendo a la vista la opinión de la doctrina nacional, las sentencias han comenzado a tomar partido por una u otra visión doctrinal en las que siempre se presenta un punto de inflexión no lógico resultante de analizar la existencia del supuesto de procedencia de la institución. Y es aquí donde se centra el mayor de los problemas: se parte considerando al artículo 61 de la LMC como la norma que fija el supuesto de procedencia -dedicación al cuidado de los hijos o a las labores propias del hogar común de uno de los cónyuges que no pudo desarrollar una actividad remunerada o lucrativa durante el matrimonio, o lo hizo en menor medida de lo que podía y quería-, para luego sentirse libres para no probar esas circunstancias o bien no vincular dicho supuesto de procedencia al análisis que exige el artículo 62 de la Ley de Matrimonio Civil o bien estimar que basta que se pruebe que el cónyuge demandante de compensación no trabajó, olvidando la expresión "de lo que podía y quería” que contempla el artículo 61 de la LMC. ${ }^{32}$ Una mayor libertad aún ha existido al momento de cuantificar por el juez

${ }^{30}$ Ver Guerrero, J. L., cit. n. 3.

${ }^{31}$ Por ejemplo, Corte de Apelaciones de Talca, sentencia de fecha 10 noviembre de 2006 , Rol 359-06, “Contreras con Opazo" (Nro Id. LexisNexis 36.113), señaló: "Es evidente que una mujer sin una ilustración especial que le hubiera permitido desempeñar una profesión, queda en una grave desventaja económica con la separación de hecho. Si ella ha demandado de alimentos a éste, y con ellos ha vivido hasta el momento, declarado que sea el divorcio, procede anular dicha pensión y acoger su demanda de compensación económica, estableciéndola en el pago de un sueldo vital remuneracional mensual por el término de diez años, a contar del mes siguiente a aquel que deje de percibir la pensión alimenticia”. En igual sentido Corte de Apelaciones de Antofagasta, sentencia de fecha 13 de abril de 2006, Rol 120-06, "Saldías con Araya" (disponible en www. poderjudicial.cl), señala: "Que si bien la ley requiere proteger al cónyuge más débil, también debe dejarse sentado que las personas divorciadas tienen el derecho de rehacer su vida y mirar hacia el futuro con la idea de que se ha resuelto definitivamente una unión que no prosperó, dejando a la sensibilidad y afectividad de cada uno de ellos, la calidado intensidad de los lazos familiares, sin que al Derecho le sea lícito entrometerse, de tal manera que, desde este punto de vista, las pensiones vitalicias o de alimentos pugnan con el divorcio y sólo deberá establecerse en casos extremos de cónyuges desvalidos que no tengan posibilidad de ejercer el derecho de alimentos en otras personas, especialmente los hijos que fueron objeto de su esfuerzo personal en la crianza y cuidado"; pero, a renglón seguido, la Corte condena al demandado reconvencional a "sesenta ingresos mínimos mensuales fijados para efectos remuneracionales, a razón de uno mensual a contar de la fecha que quede ejecutoriada esta sentencia"; es decir y como se puede apreciar, si bien no es vitalicia la compensación económica fijada, su forma de pago responde claramente a la arraigada mentalidad asistencial, que, una vez más, se impone [...] Para un mayor análisis de esta sentencia, ver Guerrero Becar, José Luis, cit. n. 3.

${ }^{32}$ Por ejemplo, sentencia de Corte de Apelaciones de Antofagasta, 31 de octubre de 2005, "Vargas con Calderón”, Rol 744-2005, Ministro redactor Oscar Clavería Guzmán, señala: “Además de criar a los menores, el solo becho de dedicarse al cuidado de los hijos y a las labores propia del hogar común, sin ejercer una profesión u oficio remunerados implica un menoscabo económico y estratificador para conseguir un empleo luego de la crianza aludida; situación que previó el legislador en el artículo 61 LMC", o Corte de Apelaciones de La Serena, "Corral con Bertolino", Rol 977-2005, 2 de diciembre de 2005, que dispuso: "En efecto, la atenta lectura del artículo 61 
la compensación económica, ya que generalizadamente no se fundamenta de manera alguna la cifra fijada. ${ }^{33}$

Intenté una primera lectura de interpretación restrictiva ${ }^{34}$ de la compensación económica en cuanto tiene como supuesto único de procedencia el artículo 61 de la LMC, es decir, que la compensación económica es procedente sólo si se produce un menoscabo económico producto de haberse dedicado uno de los cónyuges al cuidado de los hijos o a las labores propias del hogar común, no pudiendo desarrollar una actividad remunerada o lucrativa durante el matrimonio, o lo hizo en menor medida de lo que podía y quería; y de este modo el artículo 62 tendría como única función cuantificar esta especial causal de menoscabo económico. En una visión restrictiva, sin los requisitos del supuesto del artículo 61 de la LMC, el artículo 62 no es aplicable. Por tanto, estamos frente a un caso de pérdida de una oportunidad o una chance que produce un empobrecimiento del cónyuge acreedor y un enriquecimiento del cónyuge que pudo desarrollar libremente su actividad lucrativa sin preocuparse mayormente del cuidado del hogar y los hijos comunes.

Sin embargo, cabe reconocer que de la aplicación estricta de esta interpretación surgen innumerables problemas, desde luego la determinación de su procedencia y cuantificación, pero además deja fuera casos que violentan el artículo $3^{\circ}$ de la LMC en cuanto a la protección del cónyuge más débil, como, por ejemplo, en los siguientes supuestos: cónyuge que no trabajó durante el matrimonio y no tuvo a su cargo el cuidado del hogar o hijos comunes por razones de enfermedad grave; o bien la mujer que trabajó en doble jornada: sin descuidar el cuidado del hogar e hijos comunes e igualmente realizó actividades remuneradas ${ }^{35}$ con igual o mayor intensidad que su cónyuge. Por otro lado, las razones de cuantificación del artículo 62 de la LMC tampoco son muy coherentes con un análisis estricto de las causales del artículo 61 de la LMC, es fácil advertir que

LMC. lleva a concluir, sin duda alguna, que la opción libre o voluntaria de la mujer de dedicarse al cuidado de los hijos o a las labores propias del hogar, independientemente de las circunstancias de poder o no desarrollar una actividad remunerada o lucrativa, no constituye causa legal para negar la compensación en estudio". En sentido contrario, Corte de Apelaciones de Valdivia causa Rol 959-2005, "Monsalve con Jiménez", que dispuso: "Que el presupuesto de procedencia de la compensación económica, de conformidad con lo que dispone el artículo 61 de la ley 19.947 es que, si como consecuencia de haberse dedicado al cuidado de los hijos o a las labores propias del hogar, uno de los cónyuges no pudo desarrollar una actividad remunerada o lucrativa, o lo bizo en menor medida de lo que podía y quería, situación que de acuerdo con el mérito de los antecedentes no se encuentra establecida. En efecto de la prueba rendida no resulta evidente que la cónyuge haya quedado marginada de realizar actividades remuneradas, consta por el contrario que se perfeccionó y tuvo participación en actividades lucrativas". Todas las sentencias mencionadas disponibles en www. poderjudicial.cl

${ }_{33}$ Por ejemplo, Corte de Apelaciones de Santiago revoca una sentencia de primera instancia que rechazó la compensación económica, y en su reemplazo declara simplemente: "Se revoca la sentencia en alzada en cuanto no dio lugar a la demanda reconvencional de fojas 47 y en su lugar se declara: a) Que se hace lugar a la compensación solicitada y se fija en la suma de \$24.000.000. - (veinticuatro millones)”, lo anterior sin fundamentación alguna de cómo se llega a dicha cifra. Corte de Apelaciones de Santiago, Rol 9287-05, sentencia de fecha 21 de marzo de 2006, "Sabag con León”. Esta sentencia luego fue casada por la Corte Suprema de Justicia, causa Rol 2234-06, sentencia de fecha 27 de noviembre de 2006, disponible en www.poderjudicial.cl

34 Ver Guerrero, J. L., cit. n. 3.

${ }^{35}$ La denominada mujer trabajadora de doble jornada: trabajo y hogar. 
muchos de ellos se alejan del concepto de costo de oportunidad, o enriquecimiento sin causa en que trata de fundar la institución la mayoría de la doctrina, como es el caso de la buena o mal fe, o el estado de salud del cónyuge, los que sí tienen que ver con el menoscabo que produce la ruptura matrimonial en cuanto a la vida económica futura y nada que ver con que alguien haya trabajado o no en el matrimonio. Piénsese que ni siquiera menciona el legislador como un criterio a seguir, aunque éstos no sean taxativos, el monto de los ingresos que percibió el cónyuge deudor o lo que conforme a su calificación y posibilidad de acceso al mercado laboral podría haber efectivamente percibido el cónyuge acreedor, lo que, por lo demás, ayudaría mucho a la cuantificación del costo de oportunidad perdido.

Las distintas posturas doctrinales y jurisprudenciales, es justo señalar surgen del hecho de que la vinculación entre los artículos 61 y 62 de la LMC no es clara en sus textos, de este modo, el problema de interpretación es identificable y tiene su causa en la redacción del artículo 62 de la LMC, que dispone "Para determinar la existencia del menoscabo económico y la cuantía de la compensación, se considerará $[$....]".

Si este artículo dispusiera: "Para determinar la cuantía de la compensación económica, se considerará:" no habría dificultad de interpretación armónica entre los artículos 61 y 62 de la LMC ya que el 61 de la LMC definiría el menoscabo a compensar y el 62 de la LMC, lo cuantificaría; pero al expresar el artículo 62 de la LMC: "Para determinar la existencia del menoscabo económico y la cuantía de la compensación” permite entender que la existencia del menoscabo tiene su causa no sólo en los supuestos del artículo 61 de la LMC sino también en todos los supuestos del artículo 62 de la LMC, que ya no cumplirían sólo la función de criterios de cuantificación sino que cada uno de ellos puede determinar autónomamente la procedencia o existencia de un menoscabo económico.

De esta forma, es posible sostener que en el artículo 61 de la LMC el legislador trata sólo uno de los supuestos de menoscabo económico al cual le entrega un reconocimiento especial: la compensación del trabajo doméstico, esto es, la pérdida de una chance económica en la vida por dedicarse al trabajo doméstico, intención que se reitera en el mensaje de la Ley $\mathrm{N}^{\circ}$ 20.239, a la cual ya nos hemos referido y que vincula la compensación económica derechamente a los supuestos del artículo 61 de la LMC, y más específicamente al "aporte económico del trabajo doméstico".

Por otro lado, el artículo 62 de la LMC va más lejos: permite la existencia de menoscabos económicos cuyo origen no es el la actividad lucrativa realizada o no durante el matrimonio, sino que la causa es el término mismo del matrimonio y ello derivado de circunstancias que para el cónyuge más débil no representaban un menoscabo mientras el matrimonio estaba vigente ya que estaba amparado por todo un estatuto protector de índole patrimonial como el derecho de alimentos, derechos sucesorios, bienes familiares, etc., y que al terminarse el matrimonio le pone fin (Art. 60 de la Ley de Matrimonio Civil). Lo anterior, hace notar un desequilibrio económico y hace necesaria una reparación por razones de salud, edad, situación patrimonial, etc., es decir, aunque no haya existido trabajo doméstico, es posible que se presente un menoscabo económico producto del término del matrimonio. 
Valida la autonomía propuesta del artículo 62 de la LMC, para determinar la existencia del menoscabo económico, el artículo 80 de la Ley 20.255 que dispone " $A l$ considerar la situación en materia de beneficios previsionales a que se refiere el artículo 62 de la Ley $N^{\circ} 19.947$, sobre Matrimonio Civil, y ello origine total o parcialmente un menoscabo económico del que resulte una compensación, el juez, cualquiera haya sido el régimen patrimonial del [...]”. Esto quiere decir que es posible que el menoscabo surja y se determine exclusivamente de la situación previsional del cónyuge que demanda compensación.

Al tenor de esta normativa resulta indiscutido que el legislador ha previsto que el menoscabo surja directamente del análisis comparativo de la situación de beneficios previsionales de ambos cónyuges y no de un menoscabo que necesariamente emane del supuesto del artículo 61 LMC en que la situación previsional sólo cumplía una función de cuantificación. La Ley $\mathrm{N}^{\circ} 20.255$ es clara: la revisión de la situación previsional puede "originar total o parcialmente un menoscabo económico" y además se preocupa de determinar la forma específica de compensarlo: el tribunal "podrá ordenar el traspaso de fondos desde la cuenta de capitalización individual afecta al decreto ley $N^{\circ} 3.500$, de 1980, del cónyuge que deba compensar a la cuenta de capitalización del cónyuge compensado o de no existir ésta, a una cuenta de capitalización individual, que se abra al efecto. Dicho traspaso no podrá exceder del 50\% de los recursos acumulados en la cuenta de capitalización individual del cónyuge que debe compensar, respecto de los fondos acumulados durante el matrimonio". Dichos fondos no son una cifra de reparación indemnizatoria, no son de libre disponibilidad del cónyuge acreedor, por el contrario, quedan sujetos a la legislación general en materia previsional ya que se suman al fondo de capitalización individual y deberán sujetarse a las disposiciones del DL 3.500, sirviendo sólo de base a una pensión de vejez. El sentido por tanto no es de mera reparación sino de previsión hacia el futuro. ${ }^{36}$

Lo anterior nos permite colegir que el menoscabo que se "compensa" es autónomo, distinto a aquel que consagra el artículo 61 de la LMC. Así puede darse el caso de una cónyuge que trabajó cuando pudo y quiso y no obstante al momento del término del matrimonio presentar un desequilibrio importante en materia previsional en relación a su cónyuge, lo que será muy probable en Chile atendidas las menores remuneraciones que perciben las mujeres frente a iguales puestos de trabajo. ¿Puede el juez fijar compensación por ese solo menoscabo? Del tenor literal del artículo 80 de la Ley 20.255, norma especial, parece perfectamente sostenible.

En todo caso, aun sin la existencia de la Ley $\mathrm{N}^{\circ} 20.255$ creo que es posible sostener una interpretación de los artículos 61 y 62 de LMC que permita a partir de su tenor literal conciliarlos. Ello es posible, siguiendo las reglas de interpretación de la ley; en

${ }^{36}$ Cabe tener presente que en las restantes modalidades de pago de compensación económica, especialmente pago único o en cuotas definidas, nada asegura que el cónyuge acreedor destine esos fondos a rehacer su vida y prever problemas de salud o previsión en una vida futura separada. Perfectamente puede recibir una cifra importante de dinero y consumirla al día siguiente. Con la Ley $\mathrm{N}^{\circ} 20.255$, por el contrario, se asegura que esos fondos serán destinados a compensar lo que pierde por el divorcio, por ejemplo, los beneficios previsionales que habría percibido de continuar el matrimonio tienen un marcado sentido asistencial que es perfectamente compatible con el Art. 3 de la LMC. 
efecto, el artículo 19 del Código Civil prescribe en su inciso segundo que "[...] Pero bien se puede para interpretar una expresión obscura de la ley, recurrir a su intención o espíritu, claramente manifestados en ella misma, o en la historia de su establecimiento". El texto de LMC en materia de compensación económica es oscuro, de manera que estas disposiciones deben ser interpretadas teniendo en cuenta su intención o espíritu. De la historia fidedigna de su establecimiento, resulta claro en diversos pasajes que uno de los principios rectores de la LMC, inspirador de la materia que estamos analizando, es la protección del cónyuge más débil.

La protección del cónyuge más débil cuenta con una consagración positiva en la LMC. Su artículo $3^{\circ}$ dispone: "Las materias de familia reguladas por esta ley deberán ser resueltas cuidando proteger siempre el interés superior de los hijos y del cónyuge más débil"; coherente con lo anterior, el inciso tercero de la citada disposición señala: "[... e. el juez deberá resolver las cuestiones atinentes a la nulidad, la separación o el divorcio, conciliándolas con los derechos y deberes provenientes de las relaciones de filiación y con la subsistencia de una vida familiar compatible con la ruptura o la vida separada de los cónyuges". Esta disposición nos parece trascendental a la hora de determinar y precisar los supuestos de procedencia de la institución.

De manera que para emprender dicha labor, lo primero que debemos precisar es qué entenderemos por cónyuge más débil.

Es fácil constatar que la LMC no define qué debe entenderse por cónyuge más débil. Sin embargo, de la discusión parlamentaria no cabe duda de que se legisló pensando en proteger a aquel cónyuge que se encontrará, con ocasión de la ruptura matrimonial, en un posición de desmedro económico frente al otro, ${ }^{37}$ para comenzar su vida de forma separada e independiente.

En la historia fidedigna de la LMC es claro que la noción de cónyuge más débil en principio se vinculó a la mujer, en especial a aquella que no desarrolló un trabajo remunerado por haberse dedicado a satisfacer las necesidades de su familia; así en la discusión en sala en la Cámara de Diputados se sostuvo: "La realidad indica que la mayoría de los cónyuges más débiles son mujeres, porque el 65 por ciento de ellas no tiene trabajo remunerado y muchas han dedicado su vida a atender el hogar, a los hijos y al marido. Por lo tanto, no tienen asegurada por sí mismas la atención en caso de enfermedad, de invalidez o vejez, o su propia mantención, mientras que los maridos, en su mayoría, perciben una remuneración por su trabajo y financian su previsión con el dinero de la sociedad conyugal". ${ }^{38}$ Pero también quedó constancia, de la indicación del Ejecutivo, que debía evitarse, tras la ruptura, que uno de los cónyuges quedara imposibilitado de su

${ }^{37}$ En este sentido, Hübner sostiene: "En definitiva, la Ley no define cuál es el cónyuge más débil, pero de sus diversas disposiciones denota que el equilibrio se restablecerá por la vía económica, por lo que preferentemente su marco será patrimonial, sin perjuicio de que también se consideren otros factores, como su edad, estado de salud, situación previsional”.

Es así como el cónyuge más débil será aquél que económicamente está en una situación de desmedro frente al otro [...] Hübner, A. M., "La nueva Ley de matrimonio civil: panorama y estructura general", en Corral, H. (coord.), Matrimonio civil y divorcio, Universidad de los Andes, Santiago, 2005, pp. 26-27.

${ }^{38}$ Historia de la Ley $N^{\circ}$ 19.947. Primer trámite constitucional, discusión en sala, CCDD., p. 118 
mantención y por ello - primitivamente- se pretendía facultar al juez para que adoptase ciertas medidas y para lo cual debía tener en consideración especialmente lo siguiente: "la duración del matrimonio y de la vida en común de los cónyuges; la edad, estado de salud y capacidad económica de ambos cónyuges; las facultades de sustento individual de los cónyuges, considerando especialmente las posibilidades de acceso al mercado laboral; la eventual colaboración común que hayan realizado los cónyuges a la actividad que haya servido de sustento al núcleo familiar; el aporte y dedicación brindado por los cónyuges a las labores no remuneradas que demanda el cuidado de los hijos y del hogar común; la eventual pérdida de beneficios previsionales que deriven del divorcio, y la existencia previa al divorcio de una pensión de alimentos entre los cónyuges”39.

De los pasajes transcritos resulta manifiesta la función asistencial que se quiere consignar con esta institución. ${ }^{40}$ Lo anterior no implica hacer sinónima esta función con el derecho de alimentos que detenta el cónyuge, una vez que se cumple con los otros requisitos de procedencia; es más, ello se planteó en la discusión parlamentaria, pero la alternativa fue rechazada precisamente porque ahora no se detentará el título legal para demandarlos. ${ }^{41}$ La función asistencial de la compensación económica se hace plausible en evitar con ella que exista un cónyuge más débil económicamente para iniciar su vida separada y es por ello que se le compensa el menoscabo económico sufrido tras la ruptura matrimonial. Nos parece que esta función asistencial quedó reflejada en la discusión parlamentaria al incluirse la institución y descartarse su aplicación a los casos de separación judicial porque en este caso "no solamente se mantiene el vínculo, sino que también algunos efectos especialmente de orden económico, como son los alimentos entre los cónyuges y los derechos hereditarios, lo que no ocurre con el divorcio y la nulidad. La compensación económica obedece a una lógica distinta, porque al haber divorcio o nulidad se perderán los derechos de alimentos y los hereditarios, así como otros beneficios previstos para el cónyuge, tales como los relacionados con prestaciones de salud o de carácter previsional, lo que no ocurre con la separación. ${ }^{42}$

Todo lo anteriormente expuesto permite concluir que es la norma del artículo $3^{\circ}$ de la LMC la que puede permitir dar el verdadero sentido y alcance a los artículos 61 y 62 de la LMC. Por una parte, permite delimitar los supuestos de procedencia sobre

${ }^{39}$ Dentro de las medidas propuestas y que en definitiva no se consignaron por ser incompatibles con el término del matrimonio y su estatuto protector, se mencionaban: a) Proceder a la declaración de bienes familiares. b) Constituir derechos de usufructo, uso o goce respecto de bienes que hubieren conformado parte del patrimonio familiar de los cónyuges. c) Determinar el pago de un monto o de una pensión compensatoria por un período de tiempo que no exceda de los cinco años, contados desde la fecha en que quede ejecutoriada la sentencia que decreta el divorcio. Historia de la Ley $\mathrm{N}^{\circ}$ 19.947. Primer informe de la Comisión de Constitución y Familia, p. 588.

40 Sobre la diferencia que estimo existe entre la función asistencial y el derecho de alimentos, me remito a lo dicho sobre la naturaleza jurídica asistencial, al presentar el estado de la cuestión, punto II, letra B) de este trabajo.

${ }^{41}$ En este sentido, la indicación de los senadores Chadwick, Romero y Diez al primer informe de la Comisión de Constitución y Familia. Historia de la Ley No 19.947, p. 587.

${ }^{42}$ Historia de la Ley No 19.947. Primer informe de la Comisión de Constitución y Familia, p. 600. 
la base de la protección del cónyuge más débil y por otra permite limitar la cuantía misma de la compensación pues ella debe habilitar al cónyuge beneficiario sólo a una subsistencia compatible con la ruptura o la vida separada de los cónyuges y no a obtener un resarcimiento, prestación o compensación que genere, esta vez, un empobrecimiento posmatrimonio del cónyuge deudor.

La compensación económica como institución no puede pretender compensar a un cónyuge más débil para transformar luego al cónyuge deudor en un ex cónyuge más débil, esto es, que a propósito del pago de la compensación económica quede en una situación futura más precaria que la del cónyuge acreedor. ${ }^{43}$ Por lo tanto, es el menoscabo económico lo que determina la procedencia de la institución, menoscabo que en un considerable número de casos coincidirá con el supuesto previsto en el artículo 61 de la LMC ya que dicha norma define un supuesto de compensación económica que dice relación con la pérdida del costo de oportunidad por haberse dedicado el cónyuge beneficiario al cuidado de los hijos y/o a las labores propias del hogar común, sin haber podido desarrollar una actividad remunerada como quería y podía, y que es cuantificada con los criterios del artículo 62 de la LMC. En los otros casos, el menoscabo económico -el presupuesto de procedencia de la institución- está establecido y la compensación cuantificada en el propio artículo 62, menoscabo que dice relación con el desequilibrio económico que produce el término del matrimonio por la declaración judicial de divorcio o nulidad y es éste el que debe compensarse de modo de permitir la "subsistencia" del cónyuge más débil, de modo de dar un cabal cumplimiento a lo preceptuado por el artículo $3^{\circ}$ de la LMC. Por lo anterior, el artículo 62 cumple una doble función: a) cuantificar un caso de menoscabo económico especialmente determinado en el artículo 61 y, además, b) autónomamente definir otros supuestos de procedencia o existencia -como señala el propio artículo- de menoscabo económico que nacen producto del término de la relación matrimonial.

Concluyo que el artículo $3^{\circ}$ de la LMC es el fundamento y el límite de la compensación económica, límite, por cuanto al momento de cuantificar el juez debe tener presente la función "asistencial" de permitir la subsistencia del cónyuge más débil una vez separado, y para ello tomará en cuenta como lo haría antes un juez frente a una separación de hecho: la salud, la edad, sus ingresos; pero como no se trata de alimentos, sino de una institucional asistencial que nace de un hecho concreto que es el divorcio o nulidad, el juez debe fijar una cifra única, sin perjuicio de las modalidades de pago que establezca.

La compensación económica tiene entonces una función asistencial distinta a los alimentos, pero asistencial al fin y al cabo, no es indemnizatoria ni reparatoria, es asistencial para la subsistencia del cónyuge que ha sufrido un menoscabo económico que se manifiesta y nace por el término de matrimonio. La subsistencia del cónyuge más

${ }^{43}$ Esta preocupación por el cónyuge deudor parece recogerla el legislador en el Art. 66 de la LMC en que para efectos de la modalidad del pago toma en consideración la capacidad económica del cónyuge deudor. 
débil, aquel que queda en un estado de necesidad, es el origen, fundamento y el límite de esta institución.

Ciertamente se puede rebatir la interpretación que planteo, atendido que el menoscabo económico nacería tanto de los supuestos del artículo 61 como los del artículo 62, y aun sin respecto del supuesto del artículo 61, por lo que habría bastado que el artículo 62 consagrara la reparación del menoscabo económico, una de cuyas causas puede ser el no haber trabajado durante el matrimonio. Pero puedo contraargumentar que si sólo se pensaba en la compensación económica causada por la pérdida de una oportunidad laboral, teniendo el 62 sólo una función de cuantificación, ¿para qué se usó la expresión "para determinar la existencia del menoscabo económico" en el artículo 62 si bastaba con decir en él: "para la cuantificación de la compensación se tendrían presente los siguientes criterios”, criterios que se introducen por el legislador para no transformarlo en un mero cálculo matemático de sueldos no percibidos.

Mi explicación frente al reparo inicial es que se quiso dejar establecido por el legislador que el "trabajo doméstico", como lo denomina el mensaje del proyecto de la Ley $\mathrm{N}^{\circ} 20.239$ que declara como ingreso no renta la compensación económica, es sin lugar a dudas una de las causas de menoscabo económico que se manifiesta y traduce en un desequilibrio económico al momento de un divorcio y mirando hacia una vida futura separados, de allí la redacción del artículo 61. Esta intención es muy clara de las intervenciones de la Ministra de Serman y del mensaje del Ejecutivo, es una razón de políticas públicas el declarar expresamente esta causa. Pero los legisladores contemplaron otras causas, que se pueden encontrar en el artículo 62, lo que justificaría la incorporación de la expresión "Para determinar la existencia del menoscabo económico (y la cuantía de la compensación económica) se considerará, especialmente, la duración del matrimonio y de la vida en común de los cónyuges; la situación patrimonial de ambos; la buena o mala fe; la edad y el estado de salud del cónyuge beneficiario; su situación en materia de beneficios previsionales y de salud; su cualificación profesional y posibilidades de acceso al mercado laboral, y la colaboración que bubiere prestado a las actividades del otro cónyuge". Como se puede advertir y conforme a lo ya señalado, varias de estas circunstancias nada tienen que ver con el hecho de que haya existido o no trabajo doméstico, y la compensación de éste conforme al costo de oportunidad económico sufrido, por lo que es perfectamente sustentable pensar que en el artículo 62 el legislador amplía las causales de menoscabo económico que permiten la fijación de una compensación económica.

La interpretación propuesta permite superar los inconvenientes y derechamente injusticias que presenta una aplicación estricta de los artículos 61 y 62 de la LMC, exigiendo como supuesto necesario de la compensación económica el cumplimiento de los supuestos del artículo 61 de la LMC, con lo que se excluye de la compensación económica, por ejemplo, el caso de la mujer que "trabaja en doble jornada tanto cuanto puede y quiere, o bien una mujer inválida que no puede hacerse cargo de los hijos o el hogar común por su incapacidad”.

Así parece entenderlo un sector de la jurisprudencia; por ejemplo, la Corte Suprema ha sostenido: "La explicitación en la ley de los requisitos de procedencia y los factores que la determinan, no implica que la compensación tenga una equivalencia con el menoscabo producido, 
esto es, la cuantía del menoscabo no requiere ser probada integramente, en tanto que su objeto no es restituir lo perdido por su equivalente exacto, sino sólo morigerar la situación económica desmedrada en que ha quedado uno de los cónyuges". ${ }^{44}$ Es decir, la Corte estima que no es necesario probar que la solicitante no pudo trabajar cuanto pudo y quiso, sino que determinar la existencia de un menoscabo que se produce por el divorcio. ${ }^{45}$ En igual sentido la Corte de Apelaciones de Valdivia otorgó compensación económica a una cónyuge que trabajó durante todo el matrimonio, incluso mantuvo a su marido, que en sentido estricto del artículo 61 de la LMC no era beneficiaria de la compensación económica, pero determinó: "Que si bien la actora mientras se mantuvo la convivencia trabajó y obtuvo una remuneración, que duda cabe lo bizo en un cargo o profesional, sin que ninguna alternativa tuviera de perfeccionarse en sus estudios, pues debía mantener el hogar común y pagar estudios, no sólo de sus hijas sino también del cónyuge demandado. Que los razonamientos precedentes hacen concluir a estos sentenciadores, que es plenamente procedente la compensación económica solicitada por la demandante, pues inequívocamente sufrió menoscabo económico durante la convivencia, desde que es al demandado a quien se le ha acreditado nivel de vida e ingresos cuantiosos y no a la demandada". ${ }^{46}$ La Corte en este caso realiza un análisis de comparación patrimonial al momento del divorcio, abstrayéndose de las circunstancias del artículo 61 de la LMC, estableciendo que el cónyuge más débil era la demandante.

La doctrina nacional en general, cualquiera sea la naturaleza jurídica a la cual se adscriba de la compensación económica, ya sea que dé una aplicación amplia o limitada del Art. 62 de la LMC, restringe las causas de procedencia al pasado -y no al momento del divorcio- y con mayor o menor convicción hace siempre presente la necesidad de cumplir en todo caso con los supuestos del artículo 61 de la LMC, con lo cual excluyen una serie de casos de cónyuges más débiles que ya hemos mencionado, como la de la mujer que trabaja en "doble jornada” pero que igualmente es más débil que su cónyuge.

${ }^{44}$ Causa "Enrique Ramos Garrido con María Astorga Ossa”, Corte Suprema por sentencia de fecha 28 de noviembre de 2007, Rol 1787-2007, Número Identificador LexisNexis: 37721.

45 En igual sentido, Corte de Apelaciones de Talca, sentencia 10 noviembre de 2006, Rol 359-06, "Contreras con Opazo" (cit. n. 29), ha señalado: "Es evidente que la mujer, sin ilustración especial que le bubiera permitido desempeñar una profesión, quedó en una grave desventaja económica con la separación de hecho, lo que la llevó a demandar de alimentos con los cuales ha vivido hasta el momento. Declarado que sea el divorcio, se anula dicha pensión de alimentos con lo que la mujer sufre una consecuencia que el legislador no ba querido, de manera tal que, se acogerá su demanda de compensación económica; pero no en la forma alambicada que se pidió, sino estableciéndola en el pago de un sueldo vital remuneracional mensual por el término de diez años, a contar del mes siguiente a aquel que deje de percibir la pensión alimenticia, apreciado todo lo anterior de acuerdo a las reglas de la sana crítica. (Considerando Quinto, Corte de Apelaciones de Talca). El recurso de casación fue desestimado por la Excma. Corte Suprema Rol 794-2007. Nro identificador LexisNexis 36113.

${ }^{46}$ Corte de Apelaciones de Valdivia, sentencia de 7 de julio de 2006, Véjar con Soto Rol 196-2006, en Turner S., cit. n. 3, pp. 265-273. La autora critica este fallo señalando: "Aunque parezca de justicia material [...] la doctrina nacional ha recalcado que la compensación económica es una institución de derecho estricto, es decir, que sólo procede cuando concurren los presupuestos legales señalados en el art. 61 LMC, que no se presume sino que requiere de prueba y que no pretende una nivelación ex post de las relaciones patrimoniales derivadas del matrimonio sino el resarcimiento del menoscabo económico sufrido por el cónyuge beneficiario". 
Estimo que estas exclusiones violentan el Art. 3 de la LMC que prima por sobre las restantes normas de la LMC al disponer: "Las materias de familia reguladas por esta ley deberán ser resueltas cuidando proteger siempre el interés superior de los hijos y del cónyuge más débil. Conociendo de estas materias, el juez procurará preservar y recomponer la vida en común en la unión matrimonial válidamente contraída, cuando ésta se vea amenazada, dificultada o quebrantada. Asimismo, el juez resolverá las cuestiones atinentes a la nulidad, la separación o el divorcio, conciliándolas con los derechos y deberes provenientes de las relaciones de filiación y con la subsistencia de una vida familiar compatible con la ruptura o la vida separada de los cónyuges”.

Por lo anterior, la postura del "clean break" que menciona el profesor Álvaro Vidal Olivares, ${ }^{47}$ que tiene como supuesto el cumplimiento de los requisitos del artículo 61, creo que está en el sentido correcto, pero en la medida que se desvincule de una aplicación de derecho estricto del artículo 61, ya que la mirada ineludible a dicho artículo estimo que restringe la institución ya que aún no cumpliéndose los supuestos del artículo 61 -la mujer trabajó cuanto pudo y quiso- es posible que no se proteja el interés del cónyuge más débil ni se concilie la subsistencia de una vida familiar compatible con la ruptura o la vida separada de los cónyuges. Por ejemplo, supuesto el caso de la mujer que trabaja a tiempo completo con una baja remuneración, que además se preocupa prioritariamente de su hogar y del cuidado de los hijos comunes, a diferencia de su marido con altos ingresos y sólo centrado en su actividad profesional, mujer respecto de la cual se cumplen algunos de los supuestos del artículo 62 para determinar la existencia y cuantía de la compensación económica, como estado de salud, situación previsional o cualificación profesional. Pues, en este caso, en la mirada que siempre ha de revisarse primeramente el cumplimiento de los requisitos del Art. 61 de la LMC, no procedería compensación económica para esta cónyuge más débil, vulnerando creo lo dispuesto en el Art. 3 de la LMC.

Estimo que una mirada integral la entregan los artículos 3 y 60 de la LMC, cumpliendo la institución de la compensación económica una función asistencial, cuyo origen, fundamento y límite está en una vinculación económica "asistencial" que permita iniciar una vida futura separada al cónyuge más débil, por mandato del artículo 3 y permitido por el artículo 60 que dispone que el divorcio pone fin a las obligaciones y derechos de carácter patrimonial cuya titularidad y ejercicio se funda en la existencia del matrimonio, como los derechos sucesorios recíprocos y el derecho de alimentos, "sin perjuicio de lo dispuesto en el Párrafo 1 del Capítulo siguiente". Este "sin perjuicio" implica que se mantiene como obligación y derecho de carácter patrimonial aun después del matrimonio, fundado en la protección del cónyuge más débil del artículo 3 es, precisamente, la institución de la compensación económica originada por el menoscabo o detrimento económico que se produce al momento del divorcio o la nulidad para el cónyuge más débil. ${ }^{48}$

47 Ver nota 27.

${ }^{48} \mathrm{La}$ Cuarta Sala de la Corte Suprema por sentencia de fecha 28 de noviembre de 2007, Rol 1787-2007, "Enrique Ramos Garrido con María Astorga Ossa” (cit. n. 40), estimó que "la explicitación en la ley de los requisitos de procedencia y los factores que la determinan, no implica que la compensación tenga una equiva- 
Lo que sostengo en este artículo, creo que no es más que recoger la tradición de los tribunales de menores y civiles, hoy tribunales de familia, en orden a la protección del cónyuge más débil que por lo demás se recogía y probablemente de una manera mucho más clara que la actual redacción de los Arts. 61 y 62 de la LMC el proyecto de ley enviado por el Ejecutivo, que si bien fue modificado por el legislador, en la práctica parece contener la visión asistencial y la correcta lectura de las normas señaladas, pasando con la fuerza del tiempo a ser una tendencia en la jurisprudencia que cada día se acrecienta en esta mirada asistencial de la institución de la compensación económica, así como en la fundamentación del Ejecutivo en sus mensajes a las leyes que directa o indirectamente se remiten a esta institución y que se han publicado luego de la LMC. ${ }^{49}$

lencia con el menoscabo producido, esto es, la cuantía del menoscabo no requiere ser probada íntegramente, en tanto que su objeto no es restituir lo perdido por su equivalente exacto, sino sólo morigerar la situación económica desmedrada en que ha quedado uno de los cónyuges". En sentido contrario, sentencia de fecha 24 de marzo de 2008, de la misma Cuarta Sala de la Excma. Corte Suprema, Rol 53-08, "Evaristo González Martínez con María Catalán Salazar", Número. Identificador LexisNexis 38458, que establece que "aquel cónyuge que pretende la compensación económica debe solicitarla en la oportunidad procesal pertinente y acreditar en autos los presupuestos que la hacen procedente. Esta acción tiene por objeto el reconocimiento del derecho a ser resarcido por el menoscabo padecido, y la cosa pedida, la suma en que se cuantifica. Por otro lado, la causa de pedir radica en la calidad de cónyuge más débil, impedido de desarrollar una actividad remunerada o limitada en razón de lo que podía o quería, por haberse dedicado al cuidado de los hijos y a las labores propias del hogar durante la vida marital. Es por esto que no resulta suficiente probar la dedicación a los hijos y/o a las labores del hogar, sino que, además, se requiere acreditar la circunstancia de haber estado el cónyuge que la demanda en condiciones ciertas de desarrollar una actividad remunerada”.

${ }^{49}$ Cabe recordar que el texto original del mensaje del Ejecutivo otorgaba claramente una visión asistencial a las prestaciones entre los cónyuges al momento del divorcio: proyecto de ley que parecía recoger un sistema de reparación o equilibrio económico al momento de término de la relación matrimonial, que tiene un marcado carácter asistencial. En efecto, el artículo 38 del proyecto presentado por el Ejecutivo decía: "Deberá evitarse que, como consecuencia del divorcio, alguno de los cónyuges quedare imposibilitado de su mantención, considerando las resultas de la liquidación del régimen patrimonial de bienes que existiere, o el estado de separación de bienes, la existencia de bienes familiares y la eventual provisión de alimentos que hubiere existido entre ellos. Si el divorcio generare una situación de esa naturaleza, el tribunal podrá adoptar una o más de las siguientes medidas a favor del cónyuge afectado: a) Proceder a la declaración de bienes familiares; b) constituir derechos de usufructo, uso o goce respecto de bienes que hubieren conformado parte del patrimonio familiar de los cónyuges; c) determinar el pago de un monto o de una pensión compensatoria por un período de tiempo que no exceda de los cinco años, contados desde la fecha en que quede ejecutoriada la sentencia que decreta el divorcio. Para acceder a la solicitud y precisar la medida, el tribunal deberá considerar especialmente lo siguiente: $1^{\circ}$ La duración del matrimonio y de la vida en común de los cónyuges; $2^{\circ} \mathrm{La}$ edad, estado de salud y capacidad económica de ambos cónyuges; $3^{\circ}$ Las facultades de sustento individual de los cónyuges, considerando especialmente las posibilidades de acceso al mercado laboral; $4^{\circ} \mathrm{La}$ eventual colaboración común que hayan realizado los cónyuges a la actividad que haya servido de sustento al núcleo familiar; $5^{\circ} \mathrm{El}$ aporte y dedicación brindado por los cónyuges a las labores no remuneradas que demanda el cuidado de los hijos y del hogar común; $6^{\circ}$ La eventual pérdida de beneficios previsionales que deriven del divorcio; $7^{\circ} \mathrm{La}$ existencia previa al divorcio de una pensión de alimentos entre los cónyuges. Las medidas impuestas en virtud de lo dispuesto en el presente artículo no procederán respecto del cónyuge que haya dado lugar al divorcio por falta que le sea imputable”. Informe de la Comisión de Constitución, Legislación, Justicia y Reglamento, recaído en el proyecto de ley, en segundo trámite constitucional, que establece una nueva ley de matrimonio civil. Boletín 1759-18, cit. (n. 5), pp. 393-395. 


\section{BiBLIOGRAFÍA CONSULTADA}

Barrientos Grandón, Javier-Novales Alquezar, Aranzazu, Nuevo derecho matrimonial chileno, LexisNexis, Santiago, 2005, tercera edición.

Corral Talciani, Hernán, "La compensación económica en el divorcio y la nulidad matrimonial”, en Revista Chilena de Derecho, Pontificia Universidad Católica de Santiago, vol. XXXIV, enero 2007, pp. 23-40.

Court Murasso, Eduardo, Nueva Ley de Matrimonio civil (Ley 19.947 de 2004 analizada y comentada), Legis, Santiago, 2004.

Domínguez Águila, Ramón, "La compensación económica en la nueva legislación de matrimonio civil", en Actualidad Jurídica, Universidad del Desarrollo, vol. XV, 2007.

Domínguez Hidalgo, Carmen, "El convenio regulador y la compensación económica: una visión de conjunto”, en Corral Talciani, H. (coord.), Matrimonio civil y divorcio, Universidad de los Andes, Santiago, 2005.

Guerrero Becar, José Luis, "La compensación económica en la ley de matrimonio civil: análisis jurisprudencial y sobre la necesidad de revisar los supuestos de procedencia”, en Revista de Derecho, Pontificia Universidad Católica de Valparaíso, vol. XXVII, 2006, $2^{\circ}$ semestre, p. 55-94.

Hübner Guzmán, Ana María, "La nueva Ley de matrimonio civil: panorama y estructura general”, en Corral Talciani, H. (coord.), Matrimonio civil y divorcio, Universidad de los Andes, Santiago, 2005.

Pizarro Wilson, Carlos, "La compensación económica en la nueva ley de matrimonio civil chilena”, en Academia Judicial, Seminario de la Ley $\mathrm{N}^{\circ} 19.947$ de matrimonio civil, 13 y 14 de octubre de 2004.

Tapia Rodríguez, Mauricio, "La compensación económica en la ley de divorcio", en Semana Jurídica, LexisNexis No 271, Santiago, 2006.

Turner Saelzer, Susan, "La compensación económica en la ley de matrimonio civil", en Revista Chilena de Derecho, Pontificia Universidad Católica de Santiago, vol. XXXII, julio 2005.

- "Sentencia sobre requisitos de procedencia y finalidad de la compensación económica (Corte de Apelaciones de Valdivia)", en Revista de Derecho, Universidad Austral de Chile, vol. XIX, julio 2006.

- $\quad$ "Las prestaciones económicas entre cónyuges divorciados en la nueva ley de matrimonio civil", en Revista de Derecho, Universidad Austral de Chile, vol. XVI, julio 2004.

Veloso Valenzuela, Paulina, "Alguna reflexiones sobre la compensación económica", en Actualidad Jurídica, Universidad del Desarrollo, vol. XIII, 2006.

Vidal Ollvares, Álvaro, "Compensación económica en la Ley de Matrimonio Civil", en Adame Goddard, J. (coord.), Derecho Civil y Romano, Cultura y sistemas jurídicos comparados, UNAM, México, 2006.

Vidal Olivares, Álvaro, "La compensación económica en el divorcio y la nulidad matrimonial”, en Revista Chilena de Derecho, Pontificia Universidad Católica de Santiago, vol. XXXIV, enero 2007.

Vidal Olivares, Álvaro, "La compensación por menoscabo económico en la ley de matrimonio civil, en Vidal. A. \& Guzmán Brito, A. (coord.), El nuevo derecho chileno del matrimonio, Editorial Jurídica de Chile, Santiago, 2006.

Zavala Ortiz, José Luis y Montesinos Fabio, Carolina, Jurisprudencia sobre divorcio, Puntolex, Santiago, 2006. 
Sentencias

Sentencia de fecha 31 de octubre de 2005, Rol 744-2005, "Vargas con Calderón”, Corte de Apelaciones de Antofagasta, disponible en www.poderjudicial.cl

Sentencia de fecha 2 de noviembre de 2005. Rol 977-2005, "Corral con Bertolino", Corte de Apelaciones de La Serena, disponible en www.poderjudicial.cl

Sentencia de fecha 22 de diciembre de 2005, Rol 959-05, "Monsalve con Jiménez", Corte de Apelaciones de Valdivia, disponible en www.poderjudicial.cl

Sentencia de fecha 13 de abril de 2006, Rol 120-06, "Saldías con Araya", Corte de Apelaciones de Antofagasta, disponible en www.poderjudicial.cl

Sentencia de fecha 21 de marzo de 2006, Rol 9287-05, "Sabag con León”, Corte de Apelaciones de Santiago, disponible en www.poderjudicial.cl

Sentencia de fecha 10 de noviembre de 2006, C.A. de Talca, Rol 389-2006, "Contreras con Opazo", Número Identificador LexisNexis: 36.113.

Sentencia de fecha 28 de noviembre de 2007, Rol 1787-2007, "Enrique Ramos Garrido con María Astorga Ossa”, Corte Suprema, Número Identificador LexisNexis: 37721.

Sentencia de fecha 24 de marzo de 2008, Rol 53-08, "Evaristo González Martínez con María Catalán Salazar”, Corte Suprema, Número. Identificador LexisNexis 38458.

Otros

Historia de la Ley $\mathrm{N}^{\circ}$ 19.947, que Establece la Nueva Ley de Matrimonio civil, disponible en http://www.bcn.cl/histley/lfs/hdl-19947/HL19947.pdf

Circulares del Servicio de Impuestos Internos, disponibles en http://www.sii.cl 